\title{
Active participation in preventionist professional practices: a specific ergonomics training course
}

\author{
${\text { Léonard Querelle }{ }^{\mathrm{a}, *}, \text { Michel Duwelz }^{\mathrm{b}} \text {, Joffrey Beaujouan }}^{\mathrm{c}}$ and Anne Pignault ${ }^{\mathrm{d}}$ \\ ${ }^{a}$ European Ergonomist, Ergonomie \& Conception, 348 avenue Napoléon Bonaparte, 92500 Rueil-Malmaison, \\ FRANCE +33 6.03.80.21.58, ergonomie.conception@gmail.com,www.ergonomie-conception.com. \\ b INRS, Institut National de Recherche et de Sécurité, michel.duwelz@inrs.fr. \\ ${ }^{c}$ Ergonomist, ENSC, Institut Polytechnique de Bordeaux, beaujouan.joffrey@gmail.com. \\ ${ }^{d}$ Université Paris Ouest, NanterreLa Défense, anne.pignault@u-paris10.fr
}

\begin{abstract}
Currently, the different forms of corporate management methods (quality circles, lean manufacturing, etc.) are usually based on employee mobilisation. Very often, the goal of this type of approach is at best, to ensure that employees embrace corporate projects, or otherwise to impose changes on them without taking into account the real work and difficulties that they face daily. However, do these employee solicitation methods converge with participatory approaches as envisaged by ergonomists and more generally, preventionists? Based on the observation that the activity of institutional preventionists evolves with regulatory constraints and work related to the monitoring of indicators, the implementation and steering of the participatory approach within companies may be a major lever for prevention. After describing the foundations of a participatory approach, this paper will present a training experiment aimed at implementing and promoting employee participation in prevention efforts. The content of this training is then analysed with regard to the balance between methodology and the use of trainees' narratives. The results of the training session are presented from the point of view of the development prospects for pedagogical tools and the organisation of the training.
\end{abstract}

Keywords: Ergonomic work analysis, Active participation, Preventionists' professional practices, Professional narratives, Conditions and learning process

\section{Introduction}

In 1991, the European Foundation for the Improvement of Living and Working Conditions (EUROFOUND) noted that $40 \%$ of European companies surveyed did not integrate employee or employee representatives' participation. When companies approach their employees, it is mainly for "information" purposes and not to organise "consultations" or to allow their employees to take part in the decisionmaking process concerning their workstations. This is due partly to the high number of failures in terms of delays in the start-up of installations and design errors. However, many studies show the importance of developing employee participation in industrial de- sign projects (Vink [36], Hägg [13]), organisational changes (Maciel [22]), and prevention projects (Zalk [38], Hignett [13]).

Based on the observation that the activity of institutional preventionists evolves with regulatory constraints and work related to the monitoring of indicators, the implementation and steering of the participatory approach within companies may be a major lever for prevention. After describing the foundations of a participatory approach, this paper will present a training experiment aimed at implementing and promoting employee participation in prevention efforts. The content of this training is then analysed with regard to the balance between methodology and the use of trainees' narratives. The results of the training session

*Corresponding author, ergonomie.conception@gmail.com. 
are presented from the point of view of the development prospects for pedagogical tools and the organisation of the training.

\section{The participatory approach in question: from communication to "active" employee participation}

\subsection{Completely disparate notions?}

Today's most famous theory of participation may have originated in the work carried out in the $1960 \mathrm{~s}$ by Mac Gregor [21], Likert [17] and Ishikawa [16]. Initial questions on the integration of individuals in company organisation were raised by these authors. Evidently, they were already oriented towards productivity but nevertheless suggested employee participation. This was the case with the "quality circles" initiated in Japan.

Delving more specifically into the subject of this paper, the following paragraphs provide a content analysis of the documents drafted by the trainees themselves before they attended the training.

In order to identify the terms associated with the concepts of "participatory approach" and "participation", and to more closely analyse participants" notion of "participatory approach", the Alceste text analysis tool was used.

The use of the Alceste tool reduces the number of possible interpretations related to analysts' subjectivity. The method only partially objectifies the analysis, because the establishment of classes in no way provides an interpretation of the data. The corpus used in this instance was derived from work carried out by the trainees prior to the training course. They were tasked with writing a project example supported by a participatory approach in which they participated by answering the following:

Context of the action supported by a participatory approach in the company / In a few points the different stages in the approach / Duration of the action / Your position in the action / The expected and unexpected outcomes, the difficulties or circumstances that facilitated the approach / The lessons that you learned.

Ten out of twelve trainees agreed for their contributions to be analysed. Gender and age characteristics of the population were not considered since they were irrelevant for this analysis. However, it should be noted that the trainees were all prevention specialists with over ten years of experience in the field.

After converting the texts into a corpus that complied with the norms required for a computerised analysis with the Alceste software [29], the "cooccurring lexemes" in the simple statements were analysed. This type of analysis builds on the work of Benzécri [2]. The software provides statistical information on the corpus, based on which interpretations may be made.

Alceste classifies the results according to their dominant vocabulary.

In this case, three stable classes or "lexical worlds" emerged from the corpus. For each of these classes, Alceste provides access to the list of the most significant words. Analysis through the calculation of Chi2 $(\chi 2)$ serves to determine the extent to which a word belongs to a class and therefore reveals the most representative terms of a given class. In the presentation of terms, the symbol " + " indicates a contraction: for example, the word "ergonom+" may refer to "ergonomist" or "ergonomic"..

Through these classes, a relationship was established between the subjects and the participatory approach.

Class 1 (comprising 26 context units, i.e. $38.81 \%$ of the statements used in the analysis) was characterised first and foremost by an account of the intervention fields or sectors. The occurrence of the expressions construction site $+\left(\chi^{2}=8.35\right)$, construct + ion $\left(\chi^{2}=6.71\right)$, "BTP" : building and civil engineering works $\left(\chi^{2}=6.71\right)$, ground $+\left(\chi^{2}=6.71\right)$, ou regiona +1 $\left(\chi^{2}=4.95\right)$ was significant and confirmed the substantial role of context in the examples proposed by the trainees.

Class 2 (also comprising 26 context units, i.e. $38.81 \%$ of the statements used in the analysis) was made up of vocabulary related to collective work and the players concerned by this approach. The forms group $+\quad\left(\chi^{2}=18\right)$, pilot $+\quad\left(\chi^{2}=14.33\right), \quad$ objectives + $\left(\chi^{2}=10.25\right)$, médical $+\left(\chi^{2}=8.52\right)$, direction $+\left(\chi^{2}=6.71\right)$, CRAM $\left(\chi^{2}=6.71\right)$, comitee $+\left(\chi^{2}=6.71\right)$, reunion + $\left(\chi^{2}=6.38\right)$, work $+\left(\chi^{2}=5.68\right)$, position $+\left(\chi^{2}=5.5\right)$, follow $+\left(\chi^{2}=4.95\right)$ and ergonom $+\left(\chi^{2}=4.95\right)$ were widely present. This class revealed a key point in the trainees' idea of participation: although participation involved a substantial amount of players, it did not give priority to employees, contrary to what the pedagogical team believed.

Lastly, class 3 (comprising 15 context units, i.e. $22.39 \%$ of the statements used in the analysis) primarily referred to elements that either restricted or facilitated the implementation of the approach. In this class, the terms difficult $+\left(\chi^{2}=27.1\right)$, facilit + $\left(\chi^{2}=22.85\right)$, control lever $+\quad\left(\chi^{2}=18.73\right)$, relais $\left(\chi^{2}=14.75\right)$, workshop $+\left(\chi^{2}=10.89\right)$, result $+\left(\chi^{2}=7.44\right)$, inattendu $+\quad\left(\chi^{2}=6.78\right)$, waited $+\quad\left(\chi^{2}=6.78\right)$, bring + 
$\left(\chi^{2}=6.78\right)$, approach $+\left(\chi^{2}=6.58\right)$, director $+\left(\chi^{2}=4.4\right)$ highlighted the subjects' idea of the obstacles and levers as well as the expectations and outcomes related to the approach without specifically qualifying them.

To conclude with the trainees' idea of participation prior to the training session, the analysis showed that the content of the examples provided by the trainees was quite homogeneous. This homogeneity was due both to the rather uniform professional profile of the trainees (they were all prevention specialists) and to the fact that the questions asked by the pedagogical team for the purpose of drafting the examples were relatively confined. The main feature of this analysis was the absence of terms belonging to the semantic field "employees", "workers"... This analysis may suggest that employees are of secondary importance even though they occupy a key role in the description proposed in the following paragraph.

\subsection{Proposal of a provisional framework to define employee participation and the conditions required}

On the basis of a bibliographical review, this paragraph more specifically characterises ergonomics authors' understanding of participation. First, it is necessary to specify that this refers to employee participation. Garrigou's work [7] extensively showed that "employee participation in the design process, as well as the underlying socio-cognitive interaction processes" with designers are essential for the proper performance of an ergonomics intervention, and more generally, a prevention action. He envisaged the participation of operators as a methodological tool generating outcomes at several levels:

- the early preparation of employees on how to use future resources;

- fewer difficulties and less start-up time for new facilities;

- $\quad$ the setting up of a system to be used by the company's internal prevention players to monitor working conditions.

The participation process described by Garrigou [7] stresses the knowledge confrontation dimension within the company to drive improvement in working conditions. However, this confrontation is not sufficient?

\subsection{The importance of discussing real work}

Garrigou [7] recalled some of the difficulties related to the implementation of a participatory approach. One of these is power struggles that may occur between management and staff representatives, often blocking the process or even resulting in conflict. Operator knowledge is quite heterogeneous and often acquired through experience. Expressing this experience is a delicate affair for individuals, especially because it is poorly recognised since it is of an empirical nature.

Designers wield a lot of power when it comes to the design process. This is inherent to their work. They however have very little consideration for the activity or the actual end use.

Garrigou [7] proposed the concept of sociocognitive orientation to describe the manner in which corporate players explore and anticipate future working situations. He specified that a participatory approach must necessarily "enrich the register of sociocognitive orientations specific to designers and operators". In this instance, he concurred with the notion of "intermediary tools" proposed by Jeantet [13] who considered that designing was based on intermediary objects that led all or some users to work on all or some of the elements to be designed. The importance of these intermediary objects was that they focused player interactions on the actual work, through scenarios resulting from the work analysis for example.

St-Vincent et al. [32] proposed the notion of "participatory" ergonomics, which was very similar to the intervention methods described by Daniellou [7] from the industrial project implementation perspective. They considered that their proposal built on Wilson's work [35]. It drew on the "pooling and confrontation of the knowledge of ergonomists, operators, specialists" and designers throughout the ergonomic intervention. The particularity of their approach lied in the implementation of "training aimed at transferring knowledge and ergonomic assessment methods". This proposal is similar to the theoretical and field training described in particular by Martin [24]. To explain the underlying objective of this mechanism that complements the standard organisation of a traditional ergonomics intervention, it is interesting to describe the notion of "capability" derived from Sen's model [34] and reproduced taken up by Falzon [8]. Sen explained the notion of "capabilities" through the example of voting, which requires, for instance, much more than a law allowing citizens to elect a democratic government. Each citizen must 
have a sufficient level of education, free and fair access to political information and to an efficient electoral process, so as to not simply exercise a right to vote but to enjoy the "capability" to vote.

Evidently, the participatory approach relies above all on a project structure that defines the stages and organises design decision- or choice-making frameworks. However, this paper is an opportunity to discuss the matter of employees" "capability" to take part in prevention or transformation projects within companies. This "capability" has triggered a productive design debate related to "actual" work matters. The participatory approach as envisaged in this paper must draw on the specific features of the organisation (Kuorinka [18]) in order to promote employee involvement. The other fundamental elements for a successful participatory approach are the project organisation (steering committee, management committee, project leader, working groups, design meetings, etc.) and the training of players (in work analysis, plan analysis, future work simulation, use of characteristic action situations, etc.).

\section{A training case: implementing and promoting participation in a prevention approach}

\subsection{Training background}

For several years, the ergonomic analysis training organised by INRS ${ }^{1}$ (Duwelz [8],[9], Garrigou [12]) has stressed the need for operator participation in order to understand the reality of the work and activity. However, once the diagnostic has been completed, what role does operator participation and involvement play in the work situation transformation process?

The new training (experimental in 2010 and scheduled for the first time in 2011) explored the participation mechanisms in a prevention approach, as well as the methods used to integrate as much as possible the participation of trainees in a training course devoted to participation.

The first experimental training (2010) was designed in collaboration with an ergonomics consultant, a psychologist, an ergonomist a psychologist from the INRS Training Division. The reviews collected at the end of the course enabled us, after analy-

\footnotetext{
${ }^{1}$ INRS: association (Law of 01/07/1901) constituted under the aegis of the French National Health Insurance Fund. At national level, INRS is responsible for research, training, assistance and information in the domain of the prevention of work accidents and occupational diseases
}

sis, to reorganise the content, form and teaching methods of the second training course (2011). The latter was thoroughly assessed and the conclusions are presented in the last paragraph.

\subsection{Content presentation}

The training organised in 2011 took place over eight half-days. The teaching goals were to:

- clarify the position of prevention specialists in a participatory approach,

- reintegrate the participatory approach in the ergonomics approach process,

- identify and apply the different grids for group functioning analysis,

- design and apply group organisation techniques specific to the prevention approach.

The content was divided into the following themes:

- the importance of work groups in the prevention approach

- negotiation/promotion of the participatory approach

- group organisation and management techniques

- management style, analytical grids for group dynamics, players' strategies.

The training was based on three teaching methods: classic theoretical knowledge transfer, situational judgement scenarios and the use of narratives.

The theoretical knowledge transfer focused primarily on company organisation models, the different management types, group dynamics, participation in ergonomic interventions and prevention projects, and participatory design.

There were three different types of situational judgement exercises. First, "photo language" was used to explore the trainees' idea of participation and initiate a debate. The second form of participation entailed role playing in which the trainees either had to lead or defend the participatory approach. The third exercise involved requesting the trainees to summarise what they considered to be the fundamental and essential elements for a successful participatory approach.

As mentioned above, prior to the training session, the trainees had to prepare an example. The use of narratives in a pedagogical framework draws on a theoretical base addressed in the following paragraph and presented in Beaujouan's work [2].

It has been considered in several fields that, as a mediator of the reflexive processes linked to past experiences, narrative contributes significantly to 
learning [27]. In the training, it was used in a context of professional practices for learning purposes. Narratives of personal practices or those of others are a means of transmitting past experience in a training context [6],[13],[26]. Explaining experience through narrative is a key element in reflexivity development mechanisms [27]. Subsequent analysis of the narrative provides a new opportunity for episode "refiguring" as defined by Ricoeur [31], in order to understand through example the cause/effect relationship resulting in a favourable or unfavourable situation. This concurs with the notion of "practices made explicit" developed by Mayen [24] in which learners report the succession of the actions they performed as well as their goals and the parameters taken into account. A professional's analysis of these elements is important for improving his/her skill. As Pastré highlighted on several occasions, one learns more by analysing one's action rather than by reproducing it. Narrative allows for this reflection, since it allows "meaning to be created and a "meta" point of view to be adopted." [5].

As Pastré recalled, the subjects are "freed" of the concern to act, as the action can no longer be modified. The characteristics of the narrative enable subjects to understand this since they give them the opportunity to reconstruct causality out of contingencies [1]. According to Pastré, it is advisable for trainers to remember this and endeavour to develop training through "narrative", which helps trainees to better understand, through these reflexive processes, the success or failure of a past action.

Great importance was therefore given to exchanges between trainees based on their own professional experience.

\section{From the training assessment to pedagogical content development prospects}

This paragraph presents the training assessment. At the end of the course, a questionnaire was handed out to the trainees. This paragraph will present the trainees' overall assessment followed by three major possible developments that will be integrated in future training sessions.

\subsection{Overall assessment}

In order to organise the assessment, the trainees were asked five questions at the end of the course:
- Did the course meet your expectations? Please explain.

- Were the teaching goals attained? Please explain.

- Were the resources used during the course in line with the goals stated? Please explain.

- What are your thoughts about this course?

- Do you have any suggestions?

In general, the trainees gave a rather favourable assessment of the exchanges and experience sharing within the group and the situational judgement exercises. Most of them considered that the theoretical aspects were insufficient and that the group was too homogenous. All of the trainees' responses were analysed by the pedagogical team, which identified three possible improvements to be made.

\subsection{Three improvements to be made to the pedagogical content}

The initial pedagogical goal was to address participatory approach training placing emphasis on participation. Exchanges between trainees were systematically given priority, occasionally to the detriment of the initially defined content. It appears that the course was not well-balanced in this respect? Closer analysis suggests that there is not so much a need for knowledge transfer as for a more structured and formative methodological input. The pedagogical team wishes to enhance this dimension in two ways. First, the time allotted for trainee exchanges has been reduced substantially. Therefore, time for input and situational judgment scenarios with specific emphasis on participation-related tools and methods has been increased. Second, at the start of training, a summary document will be drafted by trainees. This document, which will thread through the entire training course, will present the stages involved in a participatory approach and the tools and methods available to face potential difficulties. This document will also be enriched by the collective analysis of the examples proposed by the trainees throughout the training.

Another lever for progress is the group composition. Eleven out of twelve trainees were from the same institutional organisation. Only one trainee belonged to a private company. Nevertheless, this trainee's input proved to be crucial. On the basis of this observation, the pedagogical team hopes to enhance the quality of the possible interactions between the trainees through the use of more heterogeneous professional narratives in which both the personal experiences and the activity sectors are diverse. 


\section{Conclusion}

As highlighted by St-Vincent et al. [32], [33] and Henriet [14], assisting company members to develop new skills and attaching greater importance to their idea of representation are essential for a successful participatory approach. This example illustrates the difficulty associated with training only the company's prevention specialists. In addition to the pedagogical lessons learned, it appears that it is also a matter of the activity of prevention specialists, if these specialists wish to promote and implement participation in the companies to which they provide support. In this case, these specialists face a two-fold challenge: ensuring that the company is capable of applying a participatory approach and enabling players to speak of their actual work. However, there is often the temptation to focus the design discussion on the technical layout dimensions. In our opinion, successful design, transformation and prevention projects in companies depend on the "employees' capability to participate" in these projects thanks to their skills and the conditions created by the company organisation.

\section{References}

[1] J.-M. Adam, Le récit. Vendôme: PUF, 1994

[2] J. Beaujouan, Contributions des récits professionnels à l'apprentissage d'un métier. Le cas d'une formation d'ergonomes. Thèse de Doctorat en Ergonomie. Université de Bordeaux. 2011

[3] J.P. Benzécri, Pratiques de l'analyse des données: linguistique et lexicologie. Dunod, Paris, 1981.

[4] J. Boutet, Paroles au travail. Paris: L'Harmattan, 1995.

[5] J. Bruner, L'éducation entrée dans la culture. Les problèmes de l'école à la lumière de la psychologie culturelle. Paris: Retz, 2008, [1996].

[6] A. Chené, Dire la pratique, savoir de la pratique. Cahiers de la recherche en éducation, 2(1), 1995, pp. 39-56.

[7] F. Daniellou, Les modalités de l'ergonomie de conception Introduction à la conduite de projet industriel. Cahier des notes documentaires, Sécurité et hygiène du travail, note No. 167129-87, 1987, pp. 517-523.

[8] M. Duwelz, J.F. Thibault, P. Josse, Long-term impact assessment of ergonomic training courses on professional practices, IEA, Maastricht, 2006.

[9] M. Duwelz, J.F. Thibault, P. Josse, When assessment of the changes in professional practices leads to a specific structure of ergonomic training course, in "Ergonomics in digital age", IEA 2003, XVth Triennal congress and human factors and ergonomics society, Séoul, Corée, 2003.

[10]P. Falzon, Ergonomie, conception et développement. Conférence introductive, 40ème Congrès de la SELF, Saint-Denis, La Réunion, 21-23 septembre 2005.

[11]A. Garrigou, Les apports des confrontations d'orientations socio-cognitives au sein de processus de conception participatifs: le rôle de l'ergonomie, Université Victor Segalen Bordeaux 2 - ISPED, 1992.
[12]A. Garrigou, G. Peissel-Cottenaz, Contribution à la découverte du métier des préventeurs et à la caractérisation de leurs besoins en formation continue, Note scientifique \& technique No. 244, INRS, Paris, 2004

[13] G. M. Hägg, Corporate initiatives in ergonomics: an introduction, Applied Ergonomics 34, 2003, pp 3-15.

[14]B. Henriet, Nouvelles technologies et formation dans 1'entreprise: pour une démarche participative, Revue Française de gestion, 1985.

[15] S. Hignett, J. R. Wilson and W. Morris, Finding ergonomic solutions - participatory approaches, Oxford University Press on behalf of the Society of Occupational Medicine, 55, 2005, pp 200-207.

[16]K. Ishikawa, QC Circle Activities, Juse, Tokyo, 1968.

[17]A. Jeantet, H. Tiger, D. Vinck, S. Tichkiewitch, La coordination par les objets dans les équipes intégrées de conception de produits. In G. de Terssac et E. Friedberg (s/d), Coopération et conception. Toulouse, Octarès Éditions, 1996, pp. 87-100.

[18]I. Kuorinka, Tools and means of implementing participatory ergonomics, International Journal of Industrial Ergonomics 19, 1997, pp 267-270.

[19]R. Likert, The human organization: its management and value. New-York, 1967, Mac Graw-Hill, traduction française, Le gouvernement participatif de l'entreprise, Gauthier-Villar, Paris, 1974

[20]T. Levett-Jones, Facilitating reflective practice and selfassessment of competence through the use of narratives. Nurse Educ Pract, 7(2), 2007, pp. 112-119.

[21]D. Mac Gregor, The human side of enterprise, 1960, NewYork, Mc Graw-Hill, traduction française, La dimension humaine de l'entreprise, Gauthier-Villar, Paris, 1976.

[22]R. Maciel, Participatory ergonomics and organizational change, International Journal of Industrial Ergonomics 22, 1998, pp 319-325

[23]C. Marti, Des histoires...à la gestion des connaissances : le cas de l'artisanat. Dans E. Soulier, Le storytelling, outils et applications, Paris: Lavoisier, 2006, pp. 361-385.

[24]C. Martin, L'enjeu d'une approche ergonomique: éviter que des moyens de travail ne soient mis en place à partir de représentations erronées de l'activité. In L'organisation au cœur des projets d'investissement, Travail et changement, No. 313 mars/avril 2007.

[25]P. Mayen, Le rôle des autres dans le développement de l'expérience. Education Permanente (151), 2002, pp. 87-107.

[26]A. Mercier, Des enseignants de mathématiques en formation professionnelle font l'analyse didactique de leur pratique. In C. F. Blanchard Laville, L'analyse des pratiques professionnelles. Paris: L'Harmattan, 1996, pp. 209-231.

[27]P. Pastré, Apprendre des situations. Editorial. Education Permanente, 139, 1999, pp. 7-11.

[28]P. Perrenoud, Développer la pratique réflexive dans le métier d'enseignant: professionnalisation et raison pédagogique. Issyles-moulineaux: ESF Editeur, 2001.

[29] M. Reinert, Un logiciel d'analyse lexicale (Alceste). Cahiers de l'analyse des données. 4, 1986, pp. 471-484.

[30]M. Reinert, Un logiciel d'analyse des données textuelles: ALCESTE. Communication aux 5ièmes Journées Internationales Analyse de données et Informatique, INRIA, 1987.

[31]P. Ricoeur, Temps et récit. Tome 1: L'intrigue et le récit historique, Paris: Seuil, 1983.

[32] M. St-Vincent, G. Toulouse, M. Bellemare, Démarches d'ergonomie participative pour réduire les risques de troubles musculo-squelettiques: bilan et réflexions, Réflexion sur la pratique, PISTES (C) Vol. 2 No. 1 Mai 2000.

[33]M. St-Vincent, J. Fernandez, Représentations différentielles d'ingénieurs et d'opérateurs face à une démarche d'ergonomie 
participative, 29ième congrès de la SELF, Ergonomie et Ingénierie, Volume 1, Paris, 21 au 23 septembre 1994, pp 122-128.

[34]A. Sen, Un nouveau modèle économique: développement, justice, liberté, Editions Odile Jacob, 2000.

[35]E. Soulier, L'acquisition de connaissances déférentielles dans l'interaction narrative: théorie de la descriptibilité pour la cognition distribuée. Dans E. Soulier, Le storytelling, concept, outils et applications, Paris: Lavoisier, 2006, pp. 117-176.

[36]P. Vink, M. Peeters, R.W.M. Griindemann, P.G.W. Smulders, M.A.J. Kompier, J. Dul, A participatory ergonomics approach to reduce mental and physical workload, International Journal of Industrial Ergonomics 15, 1995, pp. 389-396.

[37]J.R. Wilson, Ergonomics and participation. In J.R. Wilson \& E.N. Corlett, eds, Evaluation of Human Work: A Practical Ergonomics Methodology (Second Edition), Taylor and Francis, London, 1995, pp. 1071-1096.

[38]D. M. Zalk, Grassroots Ergonomics: Initiating an Ergonomics, Program Utilizing Participatory Techniques, British Occupational Hygiene Society, Vol. 45, No. 4, 2001, pp. 283-289. 